\title{
Utilization of Quizizz Educational Game Media to Increase Learning Interest and Achievement
}

\author{
Rina Yuliana Pratama ${ }^{1 *}$ \\ ${ }^{1}$ Fakultas Ilmu Pendidikan, Universitas PGRI Semarang, Semarang, Indonesia \\ *Corresponding author:yulianapratama@gmail.com
}

\section{Abstrak}

Pada saat menjelaskan materi guru hanya menggunakan media pembelajaran papan tulis dan bersifat monoton. Hal ini berdampak pada hasil belajar siswa yang rendah. Tujuan penelitian ini yaitu menganalisis keefektifan media pembelajaran Game Quizizz dapat meningkatan semangat dan hasil belajar. Jenis penelitian ini adalah penelitian tindakan kelas. Subyek penelitian siswa kelas IV dengan jumlah siswa 23. Data dalam penelitian ini diperoleh melalui soal pretest, soal post test yang terdapat dalam aplikasi Game Quizizz dari hasil pengamatan dan dokumentasi. Instrument yang digunakan untuk mengumpulkan data yaitu kuesioner dan tes. Teknik yang digunakan untuk menganalisis data yaitu analisis deksriptif kualitatif dna kuantitatif. Hasil penelitian yaitu siswa memperoleh persentase ketuntasan belajar sebesar 43,47\%. Setelah diberikan tindakan I mengalami peningkatan nilai rata-rata menjadi 72 dengan persentase ketuntasan belajar sebesar 60,86\% pada Siklus I. Pada siklus II mengalami peningkatan nilai rata-rata menjadi 85 dengan persentase ketuntasan belajar sebesar 95,65\%. Dari analisis di atas dapat disimpulkan bahwa penerapan media pembelajaran Game Quizizz. dapat meningkatkan minat dan prestasi belajar siswa. Implikasi penelitian ini yaitu penerapan media pembelajaran Game Quizizz dapat digunakan oleh guru untuk meningkatkan minat dan hasil belajar siswa.

Kata kunci: Game Quizizz, Saintifik, Minat, Prestasi Belajar

\section{Abstract}

When explaining the material, the teacher only uses blackboard learning media and is monotonous. This has an impact on student learning outcomes are low. This study aims to analyze the effectiveness of the Quizizz Game learning media in increasing enthusiasm and learning outcomes. This type of research is classroom action research. The research subjects were fourth-grade students with 23 students. The data in this study were obtained through pretest, post-test questions contained in the Quizizz Game application from observations and documentation. The instruments used to collect data are questionnaires and tests. The technique used to analyze the data is descriptive qualitative and quantitative analysis. The results of the study were that students obtained a percentage of learning completeness of $43.47 \%$. After being given action I, the average score was 72 , with a learning completeness percentage of $60.86 \%$ in Cycle I. In Cycle II, the average score increased to 85 with a learning completeness percentage of $95.65 \%$. From the analysis above, it can be concluded that the application of the Quizizz Game learning media can increase students' interest and learning achievement. This research implies that teachers can use the application of the Quizizz Game learning media to increase student interest and learning outcomes.

Keywords: Quizizz Game, scientific, interest, learning achievement

\begin{tabular}{|c|c|c|}
\hline History: & & Publisher: Undiksha Press \\
\hline Received & : December 28, 2020 & Licensed: This work is licensed under \\
\hline Revised & : January 20, 2021 & a Creative Commons Attribution 3.0 License \\
\hline Accepted & : June 10, 2021 & (c) (1) () \\
\hline Published & : July 25, 2021 & (1) ${ }_{E Y} S_{S A}$ \\
\hline
\end{tabular}

\section{Introduction}

Education is a universal aspect of human life. Education is also one of the efforts to improve the quality of human resources (Muhtar \& Dallyono, 2020; Wu \& Wu, 2020; Zhao et al., 2021). Without education, humans will never develop. The success of one's learning will be primarily determined by the ability to read it in understanding information (Dwigustini \& Widiya, 2020; Jatmiko et al., 2018). In addition, reading activities can also increase knowledge and information and make it easier for someone to communicate (Le et al., 2019; Shih \& Reynols, 2015). Learning is the main activity of the entire educational process in schools that aims to produce behavioral changes. These changes include cognitive, affective, and psychomotor (Yulando et al., 2019). Learning activities require active learning, 
participation, and interactive communication between teachers and students (Hermanto et al., 2021; Wu \& Wu, 2020; Yusuf \& Widyaningsih, 2020).

Innovatively designed learning activities will support the learning process (Huang et al., 2020; Smutny \& Schreiberova, 2020) Success in the learning process can be seen from understanding concepts, mastery of the material, and learning achievement (Herbert et al., 2021; Turgut \& Turgut, 2018).Students with a high conceptual understanding and mastery of the material have a higher achievement (Chiva-Bartoll et al., 2021; Ntobuo et al., 2018). In addition, the determining factor for learning success is the accuracy of the application of learning models and media (Ardini et al., 2020; Yusuf \& Widyaningsih, 2020). In comparison, the benefits of learning media are to clarify the presentation of messages and information to clarify and improve learning processes and outcomes (Maryanti \& Kurniawan, 2018; Shaik Alavudeen et al., 2021).

However, the current problem is that many teachers have not used technology for learning (Ivanov et al., 2019; Utami et al., 2018). In addition, many students do not use technology for learning (Bettencourt et al., 2011; Wungguli \& Yahya, 2020). This causes students to be lazy to study. Based on observations, students who have smartphones can only read various social media and play games. Students do not understand that smartphones are very useful in the world of education. Students must study at home for a relatively long time (Hermanto et al., 2021; Lim et al., 2021). Student learning at home is supervised by parents and online teachers (Karasmanaki \& Tsantopoulos, 2021; Katz et al., 2020).

The thematic learning process in the 2013 curriculum in class IV at SDN Kauman 05 has not implemented learning using the thematic approach ideally. The apperception carried out by the teacher has not linked the material to be studied with the previously studied material, so that the apperception carried out by the teacher does not foster interest and motivate student learning. In the learning process, the teacher has tried to integrate between subject matter, although it is still clear that the shift from one subject to another and the lack of media in learning activities.

When explaining the material, the teacher only uses blackboard learning media and is monotonous. It is still rare to use educational games to present in the delivery of subjects. Learning should also be supported by other learning media that can increase student interaction in learning so that learning materials will be easier to understand and motivate students to take part in learning (Hardiyanti et al., 2019; Masturah et al., 2018). In addition, during the learning process, students still find it challenging to group it causes a high attitude of individualism - students who have low thinking skills in working on problems. Students do not want to try to work by asking their classmates or friends around them. For that, they need to be trained to think individually and in groups (Maryanti \& Kurniawan, 2018; Yildiz \& Ersan, 2011). In addition, there are few opportunities for students to express their opinions, so it is difficult to show their participation to others, and their interest in learning is getting lower. Whereas in the 2013 curriculum, students are required to have a social character to socialize with others and achieve higher competitiveness.

Improving the quality of education can be done by making updates in the learning process (Gabriele et al., 2016; Hanif, 2020). One of them is updating the approach or learning method (Huang et al., 2020; Turgut \& Turgut, 2018). An exciting and fun learning atmosphere in the classroom needs to be realized so that the learning process can run well and educational goals can be achieved so that the quality of education increases (Anwar \& Zulkifli, 2020; Hamid et al., 2013). Efforts to create an exciting and fun learning atmosphere in the classroom require several breakthroughs in curriculum development, learning media innovation, and fulfilling educational infrastructure (Chu et al., 2021; Hermawan et al., 2018). Aspects within the scope of the learning process, learning media innovation is 
deemed necessary to increase student interest, motivation, and learning achievement (Saiboon et al., 2021; Wulandari et al., 2019).

One way to increase students' enthusiasm for learning is by using learning media (Andriyani \& Suniasih, 2021; Priantini, 2020). Learning media that can be used by teachers are game media (Partovi \& Razavi, 2019; Pratama et al., 2018). Currently students really like playing games so that learning innovation by playing games will increase students' enthusiasm for learning (Arifudin et al., 2019; Hwang et al., 2012). Games as learning media integrated with evaluation materials or questions are expected to make learning exciting and fun. The positive impact of using games is fun, and entertaining games and games provide exercises for problem-solving and logic (Albert, 2018; Kim et al., 2012).

Previous research also stated that learning media could help students learn and increase students' learning motivation (Agung et al., 2017; Safitri, 2020). The findings of previous studies also state that game media can improve student learning outcomes ( $\mathrm{Li}$ et al., 2021; Yildiz \& Ersan, 2011). It can be concluded that the learning media will help students in learning. There is no study on the use of quiz educational game media to increase student interest and achievement. The difference between this research and previous research is that educational game media use quizzes. Quizizz is a web tool program for creating interactive quiz games that are used in learning activities. The created interactive quiz has up to 4 answer options, including the correct answer and an image that can be added to the background of the question. Based on this, this study aims to analyze the effectiveness of the Quizizz Game learning media in increasing enthusiasm for learning. It is hoped that this media can improve student learning outcomes.

\section{Methods}

This type of research is classroom action research. This research was conducted at SD Negeri Kauman 05, Batang District, Batang Regency, Central Java. Research procedures are steps or methods that researchers must carry out regularly and systematically to achieve research objectives. Classroom action research is carried out in the form of an iterative cycle in which there are four main stages, namely: (a) planning, (b) action, (c) observation, and (d) reflection.

Planning is an activity carried out to make a plan used as a reference in taking action. Action implementation is an activity carried out by the teacher based on a design or plan that has been prepared. Observation is an action taken by the teacher to observe and record things that are needed and occur in implementing the action taking place. Reflection is a process to look back or review the changes that have occurred in the process of actions that have been taken. Data collection instruments are tools used to collect data and information.

This study used several data collection instruments: Teacher Activity Observation, Student Activity Observation, and Test Instruments. The next step in this research is to analyze all the data obtained during the study. The purpose of this data analysis is to answer the research problems that have been formulated. The data analysis techniques used were qualitative and quantitative statistical analysis.

\section{Results and Discussion Results}

The learning in class IV of SD Negeri Kauman 05, Batang District, Batang Regency, before using the Quizizz learning media, only used a conventional and teacher-centered model. The teacher dominates the learning process without involving students. The teacher only uses the lecture method so that students are less than optimal in exploring their abilities. Implementation tends to be monotonous and very boring for students in learning activities. 
The initial state of the students include (1) students are less active in learning; (2) learning is carried out using the lecture method so that students' attention is low and easily bored; (3) low creativity and use of methods or media that support learning.

Student learning outcomes in social studies learning on natural resource material before using the quiz game, namely the pre-cycle in class IV SD Negeri Kauman 05, Batang District, Batang Regency, have not been as expected. The pre-cycle test scores were obtained by researchers from the evaluation scores of student learning outcomes. Some of the fourthgrade students have not yet achieved complete learning. Only ten students (43.47\%) out of 23 students reached the KKM of 70. In comparison, the other 13 students $(56.53 \%)$ had not yet reached the KKM. The average value of the new class reached 67 . The percentage value of learning completeness was lower than the percentage of students who had not finished. In social studies learning on natural resource material, students have not been maximal in learning. Most students are less active in participating in learning. So this results in the evaluation of student learning outcomes is low.

They were learning after the first cycle was carried out, with an average assessment of 72. Fourteen students completed social studies learning from 23 students. To determine the level of mastery learning on the value of the first cycle, a value analysis was carried out by comparing the student's score against the minimum completeness criteria so that the number of students who had completed and had not completed was known. The following is a recapitulation table of complete learning cycle I.

Table 1. Recapitulation of Learning Completeness Cycle I

\begin{tabular}{ccccc}
\hline No & Mastery learning & Skor & The number of students & Persentase $(\%)$ \\
\hline 1 & Siswa Tuntas & $\geq 70$ & 14 & $60,86 \%$ \\
2 & Siswa Belum Tuntas & $\leq 70$ & 9 & $39,14 \%$ \\
& Total & & 23 & $100 \%$ \\
\hline
\end{tabular}

It can be seen that the percentage value of learning completeness has started to increase from before using the Quizizz educational media in Cycle I. In social studies learning on natural resource materials, students have started to look optimal in learning. Most students are already active in participating in learning. This can be seen when the researcher asks students to come forward. Many students are enthusiastic about coming forward. In addition, the condition of the class seemed active, and there were many responses from students because when the researcher asked questions, students answered in a voice filled with confidence. In this cycle, students were seen to be active and enthusiastic. The enthusiasm of students in participating in learning also began to be seen.

Student participation in learning activities in the second cycle is one student included in the assessment criteria (less) with a score of 60-74 (unfinished). At the same time, the students who entered the assessment criteria (Good) were 22 students. The highest score is 90. In this case, it has been shown that student participation in learning in Cycle II has increased by reaching $95 \%$ active participation of students. Thus, researchers expected to increase participation in learning activities with a percentage of $80 \%$ has been achieved.

Learning after the first cycle was carried out with an average assessment of 72 , and the learning was carried out again, namely Cycle II. In Cycle II learning, the value of student learning outcomes increased significantly. In Cycle I, 14 students completed social studies learning on natural resources from 23 students. With learning in Cycle II, 22 students completed while the students who did not complete were only one child.

The percentage value of learning completeness increases from before using the Quizizz learning media in Cycle I to Cycle II. In social studies learning on natural resource material, students have been very maximal in learning. Most students are already active in 
participating in learning. In addition, the condition of the class seemed very active compared to Cycle I learning, and there were many responses from students because when the researcher asked questions, students answered in a voice filled with confidence. In this Cycle, students are very active and enthusiastic. The enthusiasm of students in participating in learning is also evident, so that this resulted in the evaluation of student learning outcomes which continued to increase from Cycle I to Cycle II.

After using the educational media Quizizz game in social studies learning natural resource materials, student participation has begun to look significant compared to Cycle I. Scores of student participation in the activity. There is one student who gets the criteria (less) with a score of 60-74. While students who enter the assessment criteria. (Good) as many as 16 students with a value of 75-99 and only six students who fall into the (Very Good) criteria, namely getting a score of 100 . finished. From the evaluation results obtained completeness of $95.65 \%$, or a class average of 85 . The results of the student learning mastery test have reached $95.65 \%$. This has met the competency standards desired by the researcher, which is that more than $90 \%$ of all students scored above 90 . So it has met the KKM, which is 70 .

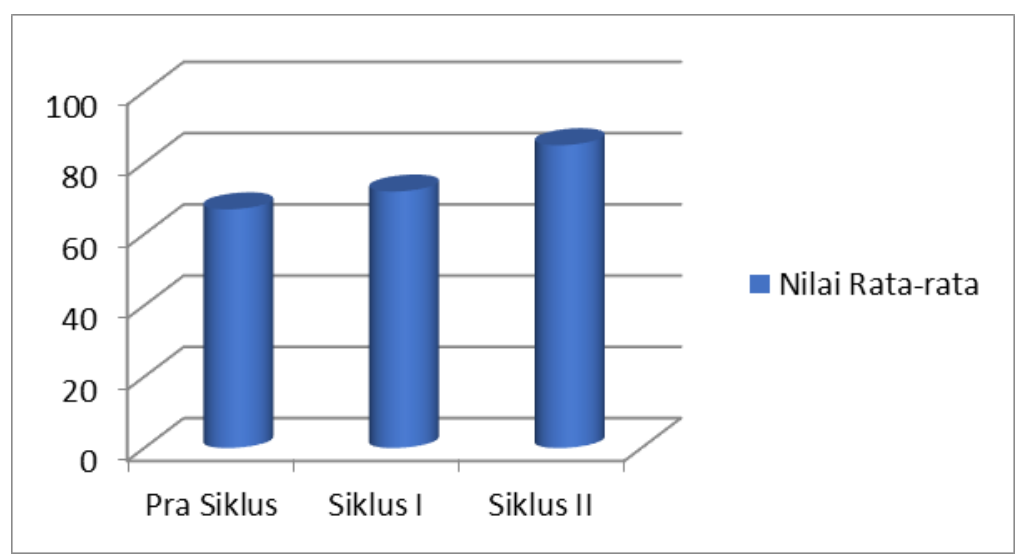

Figure 1. Graph of Improving Student Learning Outcomes

Based on the graph above, it is clear that there was an increase in student achievement and student learning completeness before and after the action was given. Before being given action with the Quizizz learning media, the average student only got a score of 67 with a learning completeness percentage of $43.47 \%$. After being given action I, the average score was 72 , with a learning completeness percentage of $60.86 \%$ in Cycle I. Similarly, in Cycle II, the average score increased to 85 with a learning completeness percentage of $95.65 \%$ of the total number of students. A total of 23 students.

\section{Discussion}

Improving the quality of education can be done by making updates in the learning process, one of which is learning media (Fauyan, 2019; Gunawam et al., 2015). Teachers must innovate in the application of learning media to increase student motivation and activity, which impacts learning outcomes ((Bergdahl et al., 2020; Hashim, 2018; Sert \& Boynueğri, 2017). Quizizz educational game media to increase student interest and achievement in social studies lessons on natural resources. Social studies learning on natural resource materials using the Quizizz educational game media can increase students' interest and achievement in learning outcomes. Learning media can also direct students' attention to lead to learning motivation that has an impact on activity and learning outcomes (Dinayusadewi et al., 2020; Gunawan et al., 2017). 
An exciting and fun learning atmosphere in the classroom is realized when the use of learning media is by the characteristics of students (Anwar \& Zulkifli, 2020; Hamid et al., 2013). Learning media can create an exciting and fun learning atmosphere in the classroom (Chu et al., 2021; Hermawan et al., 2018). Game media is one media that is highly favored by students today (Partovi \& Razavi, 2019; Pratama et al., 2018). Games are exciting for students to motivate students in learning (Arifudin et al., 2019; Hwang et al., 2012). Games as learning media that are developed are integrated with the material to make learning more exciting and fun. In addition, this game provides practice for problem solving and logic.

Previous research also stated that learning media could increase students' learning motivation so that the atmosphere becomes fun (Masturah et al., 2018; Wuryanti, 2016). Other research findings state that game media will increase students' enthusiasm for learning (Li et al., 2021; Yildiz \& Ersan, 2011). So it can be concluded that the developed media can help students in learning. This research implies that Social Studies learning can use the Quiz educational game media to improve student learning outcomes.

\section{Conclusion}

Social studies learning on natural resource materials using the Quizizz educational game media can increase students' interest and achievement in learning outcomes. Utilizing educational game media Quizizz can help students learn to increase interest and achievement of student learning outcomes in social studies lessons.

\section{References}

Agung, A. A. G., Widiana, I. W., \& Indrasuari, N. K. S. (2017). Pengembangan Aktivitas Pembelajaran Mengasosiasi Berbasis Media Gambar Berseri Dalam Meningkatkan Proses Kognitif Siswa. Jurnal Ilmiah Sekolah Dasar, 1(3), 138. https://doi.org/10.23887/jisd.v1i3.10323

Albert, P. (2018). Digital Games - a Magical Learning Tool for Slow Learners. International Journal of Research -Granthaalayah, 6(5), 407-412. https://doi.org/10.29121/granthaalayah.v6.i5.2018.1468

Andriyani, N. L., \& Suniasih, N. W. (2021). Development Of Learning Videos Based On Problem-Solving Characteristics Of Animals And Their Habitats Contain in Science Subjects On 6th-Grade. Journal of Education, 5(1), 37-47. https://doi.org/10.23887/jet.v5i1.32314

Anwar, A. I., \& Zulkifli, A. (2020). The influence of demonstration method education in the knowledge of tooth brushing in children age 10-12 years. Enfermería Clínica, 30(2). https://doi.org/10.1016/j.enfcli.2019.07.132

Ardini, L., Iswara, U. S., \& Retnani, E. D. (2020). Efektivitas Penggunaan E-Learning Sebagai Media Pembelajaran Saat Pandemi Covid 19. JKBM:Jurnal Konsep Bisnis Dan Manajemen, 7(1), 72-81. https://doi.org/10.31289/jkbm.v7i1.4333

Arifudin, D., Sulistyaningsih, E., \& Kautsar, intan adila. (2019). Optimization of The Digital Game Based Learning Instructional Design (DGBL-ID) Method as Learning Support Media. Jurnal Mantik, 3(2), 10-19. https://iocscience.org/ejournal/index.php/mantik/article/view/1092/756

Bergdahl, N., Nouri, J., \& Fors, U. (2020). Disengagement, engagement and digital skills in technology-enhanced learning. Education and Information Technologies, 25(2), 957983. https://doi.org/10.1007/s10639-019-09998-w

Bettencourt, C., Velho, J. L., \& Almeida, P. A. (2011). Biology teachers' perceptions about Science-Technology-Society (STS) education. Procedia - Social and Behavioral Sciences, 15. https://doi.org/10.1016/j.sbspro.2011.04.262 
Chiva-Bartoll, O., Ruiz-Montero, P. J., Olivencia, J. J. L., \& Grönlund, H. (2021). The effects of service-learning on physical education teacher education: A case study on the border between Africa and Europe. SAGE Journals. https://doi.org/10.1177/1356336X211007156

Chu, F., Cheng, X., Peng, C., Jia, R., \& Chen, T. (2021). A process transfer model-based optimal compensation control strategy for batch process using just-in-time learning and trust region method. Journal of the Franklin Institute, 358(1). https://doi.org/10.1016/j.jfranklin.2020.10.039

Dinayusadewi, N. P., Ngurah, G., \& Agustika, S. (2020). Development Of Augmented Reality Application As A Mathematics Learning Media In Elementary School Geometry Materials. Journal of Education Technology, 4(2), 204-210. https://doi.org/10.23887/jet.v4i2.25372

Dwigustini, R., \& Widiya, J. (2020). Think Pair Share Technique to Promote Students' Reading Comprehension. Jurnal Ilmu Pendidikan, 12(1). https://doi.org/10.37640/jip.v12i1.270

Fauyan, M. (2019). Developing Interactive Multimedia Through Ispring on Indonesian Learning with the Insight Islamic Values in Madrasah Ibtidaiyah. Al Ibtida: Journal Pendidikan Guru MI, 6(2). https://doi.org/10.24235/al.ibtida.snj.v6i2.4173

Gabriele, K. M., Holthaus, R. M., \& Boulet, J. R. (2016). Usefulness of Video-Assisted Peer Mentor Feedback in Undergraduate Nursing Education. Clinical Simulation in Nursing, 12(8), 337-345. https://doi.org/10.1016/j.ecns.2016.03.004

Gunawam, G., Harjono, A., \& Sutrio, S. (2015). Multimedia Interaktif dalam Pembelajaran Konsep Listrik Bagi Calon Guru. Jurnal Pendidikan Fisika Dan Teknologi, 1(1), 9-14. https://doi.org/10.29303/jpft.v1i1.230

Gunawan, G., Sahidu, H., Harjono, A., \& Suranti, N. M. Y. (2017). The effect of project based learning with virtual media assistance on student's creativity in physics. Jurnal Cakrawala Pendidikan, 2. https://doi.org/10.21831/cp.v36i2.13514

Hamid, R., Baharom, S., Taha, M. R., \& Kadaruddin, L. K. (2013). Competition as an Innovative Student-centered Learning Method for Open-ended Laboratory Work. Procedia - Social and Behavioral Sciences, 10. https://doi.org/10.1016/j.sbspro.2013.10.726

Hanif, M. (2020). The development and effectiveness of motion graphic animation videos to improve primary school students' sciences learning outcomes. International Journal of Instruction, 13(4), 247-266. https://doi.org/10.29333/iji.2020.13416a

Hardiyanti, Y., Husain, M. S., \& Nurabdiansyah. (2019). Perancangan Media Pengenalan Warna Untuk Anak Usia Dini. Jurnal Imajinasi Seni Dan Pendidikan, 2(2). https://doi.org/10.26858/i.v2i2.9553

Hashim, H. (2018). Application of Technology in the Digital Era Education. International Journal of Research in Counseling and Education, 1(2), 1. https://doi.org/10.24036/002za0002

Herbert, V. M., Perry, R. J., LeBlanc, C. A., Haase, K. N., Corey, R. R., Giudice, N. A., \& Howell, C. (2021). Developing a Smartphone App With Augmented Reality to Support Virtual Learning of Nursing Students on Heart Failure. Clinical Simulation in Nursing, 54. https://doi.org/10.1016/j.ecns.2021.02.003

Hermanto, Y. B., Agustini, V., \& Srimulyani. (2021). The Challenges of Online Learning During the Covid-19 Pandemic. Jurnal Pendidikan Dan Pengajaran, 54(1). https://doi.org/10.23887/jpp.v54i1.29703

Hermawan, Putro, K. H., \& Sugini. (2018). The Effectiveness of Course Review Horay Method on Social Sciences Learning Achievement of Visually Impaired Students. Journal of Icsar, 2(2). https://doi.org/10.17977/um005v2i22018p153 
Huang, S. Y., Kuo, Y. H., \& Chen, H. C. (2020). Applying digital escape rooms infused with science teaching in elementary school: Learning performance, learning motivation, and problem-solving ability. Thinking Skills and Creativity, 37(129), 100681. https://doi.org/10.1016/j.tsc.2020.100681

Hwang, G. J., Wu, P. H., \& Chen, C. C. (2012). An online game approach for improving students' learning performance in web-based problem-solving activities. Computers and Education, 59(4), 1246-1256. https://doi.org/10.1016/j.compedu.2012.05.009

Ivanov, D., Dolgui, A., \& Sokolov, B. (2019). The impact of digital technology and Industry 4.0 on the ripple effect and supply chain risk analytics. International Journal of Production Research, 57(3), 829-846. https://doi.org/10.1080/00207543.2018.1488086

Jatmiko, A., Kartina, Y., Irwandani, I., Fakhri, J., Pricilia, A., \& Rahayu, T. (2018). Reading Concept Map-Think Pair Share (Remap-TPS) Learning Model on Cognitive Ability and Scientific Attitude. Jurnal Keguruan Dan Ilmu Tarbiyah, 3(2). https://doi.org/10.24042/tadris.v3i2.3184

Karasmanaki, E., \& Tsantopoulos, G. (2021). Impacts of social distancing during COVID-19 pandemic on the daily life of forestry students. Children and Youth Services Review, 120(December 2020), 105781. https://doi.org/10.1016/j.childyouth.2020.105781

Katz, C., Priolo Filho, S. R., Korbin, J., Bérubé, A., Fouché, A., Haffejee, S., KaawaMafigiri, D., Maguire-Jack, K., Muñoz, P., Spilsbury, J., Tarabulsy, G., Tiwari, A., Thembekile Levine, D., Truter, E., \& Varela, N. (2020). Child maltreatment in the time of the COVID-19 pandemic: A proposed global framework on research, policy and practice. Child Abuse and Neglect, November, 1-14. https://doi.org/10.1016/j.chiabu.2020.104824

Kim, P., Buckner, E., Kim, H., \& Makany, T. (2012). A comparative analysis of a gamebased mobile learning model in low-socioeconomic communities of India. International $\begin{array}{llll}\text { Journal of Educational } & \text { Development, }\end{array}$ https://doi.org/10.1016/j.ijedudev.2011.05.008

Le, T. T. H., Tran, T., Trinh, T. P. T., Nguyen, C. T., Nguyen, T. P. T., Vuong, T. T., Vu, T. H., Bui, D. Q., Vuong, H. M., Hoang, P. H., Nguyen, M. H., Ho, M. T., \& Vuong, Q. H. (2019). Reading habits, socioeconomic conditions, occupational aspiration and academic achievement in Vietnamese junior high school students. Sustainability (Switzerland), 11(18), 1-29. https://doi.org/10.3390/su11185113

Li, F.-Y., Hwang, G.-J., Chen, P.-Y., \& Lin, Y.-J. (2021). Effects of a concept mappingbased two-tier test strategy on students' digital game-based learning performances and $\begin{array}{lllll}\text { behavioral } & \text { patterns. } & \text { Computers }\end{array}$ https://doi.org/10.1016/j.compedu.2021.104293

Lim, M. T. C., Ramamurthy, M. B., Aishworiya, R., Rajgor, D. D., Tran, A. P., Hiriyur, P., Kunaseelan, S., Jabri, M., \& Goh, D. Y. T. (2021). School closure during the coronavirus disease 2019 (COVID-19) pandemic - Impact on children's sleep. Sleep Medicine, 78(January 2020), 108-114. https://doi.org/10.1016/j.sleep.2020.12.025

Maryanti, S., \& Kurniawan, D. T. (2018). Pengembangan Media Pembelajaran Video Animasi Stop Motion Untuk Pembelajaran Biologi Dengan Aplikasi Picpac. Jurnal BIOEDUIN: Program Studi Pendidikan Biologi, 8(1), 26-33. https://doi.org/10.15575/bioeduin.v8i1.2922

Masturah, E. D., Mahadewi, L. P. P., \& Simamora, A. H. (2018). Pengembangan Media Pembelajaran Pop-Up Book pada Mata Pelajaran IPA Kelas III Sekolah Dasar. Jurnal EDUTECH Universitas Pendidikan Ganesha, 6(2), 212-221. https://doi.org/10.23887/jeu.v6i2.20294

Muhtar, T., \& Dallyono, R. (2020). Character Education From the Perspectives of Elementary School Physical Education Teachers. Jurnal Cakrawala Pendidikan, 39(2), 
395-408. https://doi.org/10.21831/cp.v39i2.30647

Ntobuo, N. E., Arbie, A., \& Amali, L. N. (2018). The Development of Gravity Comic Learning Media Based on Gorontalo Culture. Jurnal Pendidikan IPA Indonesia, 7(2), 246-251. https://doi.org/10.15294/jpii.v7i2.14344

Partovi, T., \& Razavi, M. R. (2019). The effect of game-based learning on academic achievement motivation of elementary school students. Learning and Motivation, 68. https://doi.org/10.1016/j.lmot.2019.101592

Pratama, D., Wardani, W. G. W., \& Akbar, T. (2018). The Visual Elements Strength in Visual Novel Game Development as the Main Appeal. MUDRA: Jurnal Seni Budaya, 3(3). https://doi.org/10.31091/mudra.v33i3.455

Priantini, D. A. (2020). The Development Of Teaching Video Media Based On Tri Kaya Parisudha In Educational Psychology Courses. Journal of Education Technology, 4(4). https://doi.org/10.23887/jet.v4i4.29608

Safitri. (2020). Pengembangan Media Board Game untuk Pembelajaran Tematik di Sekolah Dasar. Jurnal Inovasi Pembelajaran, 6(2). https://doi.org/10.22219/jinop.v6i2.8186

Saiboon, I. M., MSurg, Nurmaimun, Noriani, Shamsuddin, N. S., \& Johar, M. (2021). Effectiveness of Self-Directed Small-Group-Learning Against Self-Directed IndividualLearning Using Self-Instructional-Video in Performing Critical Emergency Procedures Among Medical Students in Malaysia: A Single-Blinded Randomized Controlled Study. Clinical Simulation in Nursing, 56(1). https://doi.org/10.1016/j.ecns.2021.02.006

Sert, N., \& Boynueğri, E. (2017). Digital technology use by the students and english teachers and self-directed language learning. World Journal on Educational Technology: Current Issues, 9(1), 24. https://doi.org/10.18844/wjet.v9i1.993

Shaik Alavudeen, S., Easwaran, V., Iqbal Mir, J., Shahrani, S. M., Ali Aseeri, A., Abdullah Khan, N., Mohammed Almodeer, A., \& Abdullah Asiri, A. (2021). The influence of COVID-19 related psychological and demographic variables on the effectiveness of elearning among health care students in the southern region of Saudi Arabia. Saudi Pharmaceutical Journal. https://doi.org/10.1016/j.jsps.2021.05.009

Shih, Y.-C., \& Reynols, B. L. (2015). Teaching Adolescents EFL by Integrating Think-PairShare and Reading Strategy Instruction: A Quasi-Experimental Study. RELC Journal, 6(1). https://doi.org/10.1177/0033688215589886

Smutny, P., \& Schreiberova, P. (2020). Chatbots for learning: A review of educational chatbots for the Facebook Messenger. Computers \& Education, 151. https://doi.org/10.1016/j.compedu.2020.103862

Turgut, S., \& Turgut, I. G. (2018). The effects of cooperative learning on mathematics achievement in Turkey: A meta-analysis study. International Journal of Instruction, 11(3), 663-680. https://doi.org/10.12973/IJI.2018.11345A

Utami, T. N., Jatmiko, A., \& Suherman, S. (2018). Pengembangan Modul Matematika dengan Pendekatan Science, Technology, Engineering, And Mathematics (STEM) pada Materi Segiempat. Desimal: Jurnal Matematika, 1(2), 165. https://doi.org/10.24042/djm.v1i2.2388

$\mathrm{Wu}, \mathrm{T} . \mathrm{T} .$, \& Wu, Y. T. (2020). Applying project-based learning and SCAMPER teaching strategies in engineering education to explore the influence of creativity on cognition, personal motivation, and personality traits. Thinking Skills and Creativity, 35(January), 100631. https://doi.org/10.1016/j.tsc.2020.100631

Wulandari, T. A. J., Sibuea, A. M., \& Siagian, S. (2019). Pengembangan Media Pembelajaran Berbasis Multimedia Interaktif Pada Mata Pelajaran Biologi. Jurnal Teknologi Informasi \& Komunikasi Dalam Pendidikan, 5(1), 75-86. https://doi.org/10.24114/jtikp.v5i1.12524

Wungguli, D., \& Yahya, L. (2020). Pengaruh Penggunaan Media Berbasis Information and 
Communication Technology (ICT) terhadap Hasil Belajar Siswa pada Materi Dimensi Tiga. Jambura Journal of Mathematics Education, 1(1), 41-47. https://doi.org/10.34312/jmathedu.v1i1.5376

Wuryanti. (2016). Pengembangan Media Video Animasi untuk Meningkatkan Motivasi Belajar dan Karakter Kerja Keras Siswa Sekolah Dasar. Jurnal Pendidikan Karakter, 6(2). https://doi.org/10.21831/jpk.v6i2.12055.

Yildiz, S., \& Ersan, Y. (2011). A study on pc - video games in terms of the space awareness from childhood to youth. Procedia - Social and Behavioral Sciences, 28. https://doi.org/10.1016/j.sbspro.2011.11.145

Yulando, S., Sutopo, S., \& Franklin Chi, T. (2019). Electronic Module Design and Development: An Interactive Learning. American Journal of Educational Research, 7(10), 694-698. https://doi.org/10.12691/education-7-10-4

Yusuf, I., \& Widyaningsih, S. W. (2020). Implementing e-learning-based virtual laboratory media to students' metacognitive skills. International Journal of Emerging Technologies in Learning, 15(5). https://doi.org/10.3991/ijet.v15i05.12029

Zhao, Y., Llorente, A. M. P., \& Gómez, M. C. S. (2021). Digital competence in higher education research: A systematic literature reviewNo Title. Computers \& Education, 168. https://doi.org/10.1016/j.compedu.2021.104212 